\title{
THE STUDENTS' ABILITY IN CONSTRUCTING NEW WORDS USING DERIVATIONAL AFFIXES
}

\author{
RAMLAN \\ Dosen Prodi Bahasa Inggris FKIP Universitas Jabal Ghafur \\ ramj.kajhu@yahoo.com contect number +62 81361021208
}

\begin{abstract}
Bahwa bahasa adalah alat komunikasi yang tidak bisa dihindari dalam kehidupan kita sehari-hari. Bahasa, di samping itu juga, diakui sebagai instrumen yang paling sempurna sebagi alat komunikasi. Karena bahasa itu sendiri merupakan bagian dari budaya, perlu untuk mempertahankan dan mengembangkannya. Karena itu Penelitian ini berkaitan dengan proses pembentukan kata melalui penambahan imbuhan (affixes) yang ditambahkan bisa sebelum, sesudah atau di dalam stem atau base form (kata dasar dari suatu kata) untuk menghasilkan kata baru yaitu bagaimana suatu kata dibentuk, terutama dari kata akhiran : -ment, -ance/-ence, -ion, -sion, -ission, -tion, -ary, and -ness. Tujuan dari penelitian ini adalah mendeskripsikan kemampuan siswa dalam membangun kata-kata baru dari kata-kata dasar dengan proses penambahan imbuhan kata dan untuk menggambarkan kesulitan siswa dalam membangun kata-kata baru dengan menggunakan kata-kata dasar dalam melakukan proses pembentukan penambahan imbuhan kata. Teknik yang digunakan dalam penelitian ini adalah deskriptif kuantitatif. Objek penelitian ini adalah kelas X Tahun 2005/2006 di SMK AL-FATAH di Jln.Cemara ada 172 Medan. Jumlah sampel yang diambil adalah 24 orang siswa dari 132 orang siswa. Tes yang diberikan adalah yang dibuat oleh guru yang terdiri dari 20 item soal dalam bentuk tes mencocok soal dan jawaban yang telah disediakan. Dari Temuan research menunjukkan bahwa hanya 18 orang siswa 75\% dikategorikan sebagai mampu. Item tes nomor 10 adalah yang paling sulit di mana hanya 5 orang siswa mampu menjawab tes.
\end{abstract}

Key Words: Pembentukan kata, imbuhan, akhiran.

\section{Introduction}

That language is a means of communication is inevitable in our lives. Language, in addition, is recognized as the most perfect instrument of communication. Since language itself is a part of the human culture, it is necessary to maintain and develop it. English as a language has succeeded to attract most people all over the world to learn it because it is an international language as a medium of global communication.

A language allows about anything within of knowledge. Knowledge is very important for human beings. As Moslem we are encouraged to get knowledge as much as possible. In relation to it, Allah in the Holly Al-Quran states in Surrah Azzumar: 9

“ Say! (Oh, Muhammad) are those who know equal with those who know not? But only their knowledge will pay need." (Azzumar: 9)

From the surrah above we can conclude that to obtain knowledge is very essential and there is a difference between the people who have knowledge and those who have not. Rasulullah Muhammad SAW said:

"Pursuit of knowledge is an obligation for all Moslems."

From this Hadist we can see the importance of having knowledge for all Moslems as an obligation in Islam as what Muhammad SAW stated. Dickey (1986:35) stated that language is a system of arbitrary vocal symbols, which permits all people in a given culture to communicate or to interact.
According to Quirk (1988: 536) language is defined as a system of signs, movements, words etc as used by people to express meanings of feelings. And Webster (1995: 80) defines language a systematic means of communicating ideas or feeling by the use of conventionalized signs, sounds, gestures, or marks having understood meanings.

English as one of International languages is used all over the world as a tool of communication whether as the first or second language. It makes the people such as those in academic world mostly use English, because textbooks and other media are available in English. In there are English four skills that should be mastered in learning it, namely listening, speaking, writing, and reading.

English is very important especially in developing human resources because much knowledge and education technology are writter in English since its function as one of the International languages. In Indonesia, English is used as the first forign. Language. Textbooks are mostly written in English, not only books used to learn English but also other disciplines. Modern human beings have to study English so that they can use it as a madium of communication to develop their knowladge.

The teaching of English is very important because it is an obligatory subject at Junior high school, Senior high school, and the university level. It is acceptable as science and technology are mostly written in English. Morphology is recognized to have two main fields. They are inflectional and derivational morphology. Derivational morphology 
studies the principle governing the construction that change the class of the word and meaning. In this study the researcher will study the above morphological process especially derivational affixes.

Derivational affixes are affixes that can change class of the word and meaning if combine with suffix and prefix. Sometimes it is misinterpreted by reader especially students in meaning. In Indonesia, English is taught as the first foreign language. Meanwhile Inflectional affixes are used to indicate aspects of the grammatical function of a word. Inflectional morphemes are used to show if a word is plural or singular, if it is past tense or not, if it is a comparative or possessive form.Rachmadie (1985: 23) gave examples of affixes and the new words as follows:

\section{DERIVATIONAL BASE DERIVATIONAL}

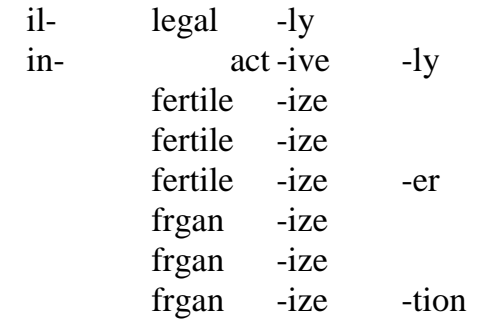

\section{INFLECTIONAL NEW WORD}

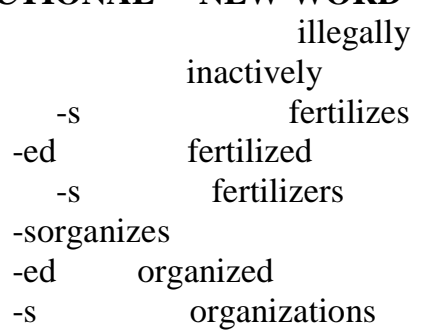

The existence and the veriety of useges of English affixes interes the writer to find weather the students are able to construct new words using derivational affixes. Some students still have problems or difficulties in constructing new words because they are not know the affixes to use. Based on that reason, the researcher would like to know the students' ability in constructing new words using derivational affixes and also to find out their difficulties in constructing the new words.

\section{Review of Literature \\ 1. Definition of Ability}

The word 'ability' derives from the word 'able' which has the similar meaning with 'can'. Hornby (1995: 20) said that ability is the skill or competence of doing something. The meaning of this word is the situation being able. It is also as potential capacity or power to doing something physical or mental.

Webster (1995: 44) says that ability is the quality or state or being able especially in physical, mental, leg as power to perform .So, based on their explanation, the researcher takes his own summary that ability is skill to take a certain attitude to watch something with understanding to create new something to prove how far the students success in learning process in their level class.

\section{Description of Morphemes}

We all know what a word is, at least in our own language. We can list as many words as possible in English and especially in Indonesian. Yet, can we explain the concept 'word'? What is a word anyway? If we don't have a quick answer to this question, we don't have to feel depressed. The concept of 'word' according to Rachmadie (1985:9) is extremely complex. Even linguists and dictionary makers have also shared our problem. But he mentioned one common definition of word as

follows: "A word is any unit of language that in writing, appears between spaces or between a space and a hyphen". Let us consider the following words: (1). Matchbox, (2). Match box, (3). Match-box. Each way of writing this form is generally considered to be correct. Yet it would certainly be awkward to call matchbox (1) a single word but to call match box (2) or matchbox (3) two words.

Nida (1974: 68) stated that morpheme is the smallest difference in the shape of word that correlates with the smallest difference in word or sentence meaning or grammatical structure. The analysis of word into morpheme begins with the isolation of morphs. A morph is a physical form representing some morpheme in a language. If different morphs represent the same morpheme, they are grouped together and they are called allomorphs of that morpheme. The relationship between morphemes, allomorphs and morphs can be represented using a diagram in the following way:

\section{Morpheme}

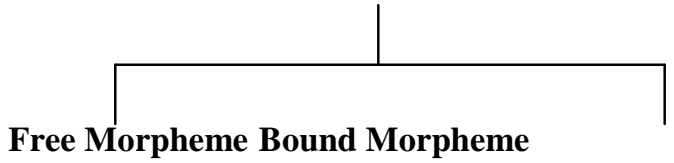

\section{Prefix Infix Suffix}

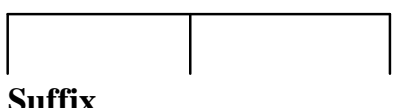

\section{Inflectional Derivational}

A morpheme may be involved in regular patterns of interchange. For instance,-est in longest gains credibility as a morpheme not only because it's what is left over when we remove the meaningful long, but also it interchanges with -er in a regular meaning relationship found in hosts of other adjectives too (softer, softest, duller, dullest and so on). Those that behave like this are the ones that are 
most firmly integrated into the language system. Coates (1999: 4) has his characteristics of the morpheme, they are: (a). Morphemes typically are meaningful, (b). Morphemes recur in a language 's vocabulary and, (c). Morphemes may recur in regular Interchanges.

It is clear then that words do not always constitute the smallest meaningful units in a language. Instead, words are sometimes constructed of smaller parts. These smaller parts are called Morphemes.

\subsection{Free Morphemes}

Yule (2001:76) defines that Free Morpheme is " Morphemes that can stand by themselves as single words." And he also described that Free Morphemes has two categories. The first category is that set of ordinary nouns, adjectives, and verbs, which we think of as the words, which carry the 'content' of message, we convey. These morphemes are called lexical Morphemesand some examples are boy, man, house, tiger, sad, long, yellow, sincere, open, look, follow, break. We can add new lexical morphemes to the language rather easily, so they are treated as an open class of words.

The other group of free morphemes is called Functional Morphemes. This sets consists of largely of the functional words in the language such as conjunction, prepositions, articles, and pronouns. For examples, and, but, when, because, on, near, above, in, the, that, it. We almost never add new functional morphemes to the language. They are described as a 'closed' class of words.

Kumar (2004: 65) explained that it should be noted that this type of description is a partial simplification of the morphological facts of English. There are a number of English words in which the element, which seems to be the 'stem' is not, in fact, free morpheme. In words like receive, reduce, repeat we can recognize the bound morpheme re-, but the elements -ceive, -duce, and-peats are clearly not free morphemes.

\subsection{Bound Morphemes}

Many roots are capable in solution. They always occur with some word building elements attached to them such roots are called bound morphemes. Examples of bound morphemes are given such as: re-, -ness, -ment, dis-, the bound root: -ness, re-, -ment, dis-, Occur with from like: -de, re-, ate, which occur in numerous other words as prefixes and suffixes. None of this root could occur as an independent word. Bound morphemes are as their names suggest, those that must be attached free morphemes.

The morphemes -ity and -ing are also bound, needing to attachthemselves to free morpheme such as "Sincere" or "sing" to form "sincerity" or "singing". Bound morpheme tends to be affixes (e.g. prefixes and suffixes). Attaching to the beginning and the ends of words. Bound morpheme must action to do something else in order for the -re meaning or function to be realized as Webster said (1995: 80).

Bound Morphemes are kind of morphemes, which are the opposite of Free Morphemes. So Bound Morphemes are " morphemes which cannot normally stand alone, but which are typically attached to another form ". In this case we also have some terms, they are stem (the basic words), roots or new bases (morphemes that serve as the basis for words), and affixes (morphemes such as -ly, -ness, ment etc). The set of affixes that falls into the 'bound ' category can also be divided into two types. One type is Derivational Morphemes. These are used to make new words in the language and are often used to make words of a different grammatical category from the stem. Thus the addition of the derivational morphemes -ness change the adjective good to the noun goodness. The noun care can become the adjective careful or careless via the derivational morphemes. -ful, or -less. A list of derivational morphemes will include suffixes such as the -ish in foolish, the -ly in badly and the -ment in payment. It will also include prefixes such as re-, pre-, ex-, dis-, co-, un-, and many more said Perrin (1979: 33). The second set of bound morphemes contains what are called Inflectional Morphemes. These are not used to produce new words in the English language, but rather to indicate aspects of the grammatical functions of a word. Inflectional morphemes are used to show if a word is plural or singular, if it is past tense or not, and if it is a comparative or possessive form.

\section{Description of Base}

Base is any unit whatsoever to which affixes of any kind can be added. According to Wardhaugh (1996: 137) Base is the form to which an affix is added. The base is also the root. The Examples are such as blackened, in which affix -ed is added to the verbal new words blacken, unit consisting of the root morpheme black and the suffix -en.

Meanwhile, base seems the same as stem too. The stem is that part of a word that is in existence before any inflectional affixes. Base is called stems only in the context of inflectional morphology.

Coates (1999:28) explaines that base is whatever we can add affixes to. The additional elements is called affixes, they are not independent. All roots are potentially bases (but not vice versa). A new words can be a plain root (e.g. switch, bottle, vanilla) or more than one root (bell-jar, windowseat). A base can also consist of a root plus one or more affixes (e.g. corny, ex-husband). The most highly structures bases may consist of more than one base, one or each of which may be: A root equipped with affixes (e.g. standoffish, dano-Norwegian, Bluey-green, rumpy-pumpy), or a new words which 
itself consists of multiple bases (e.g. railway station, ice-cream salesman).

For a more detail descreption related to the new words, let us see the following explanation:

Root : morphemes on which the rest of a word is built

Basew: any structure to which an affix may be added

Stem : any new words to which a grammatical affix may be added

Affix (1): LEXICAL affixes form separate dictionary words by being attached to new wordss (process: derivation)

Affix (2): GRAMMATICAL affixes add grammatical meanings to the meaning of their stems (process: inflection)

\section{Description of Affixes}

To have understanding to affixes the researcher has collected some definition from some experts:

(1). Lambert (1972: 295) says than an affix is a morpheme which may be attached at the beginning or and of a new words or to one more morpheme ultimately attached to such new words.

(2). Nida (1982: 197) states that an affix is morpheme, which cannot stand alone but add to a word either to change is grammatical class, to serve as grammatical marker, or to add an element of meaning.

(3). Coates (1999: 46)says that Affixation is the process or result of attaching or adding an affix the root.

The explanation above shows clearly that affixes do not or cannot stand-alone by them selves, but their addition or combination $\mathrm{p}$ new words or stem or root forms construct new words. The types of affixes are: prefixes and suffixes.

\subsection{Suffixes}

According to Yule (2001: 69) in the preceding group of words, it should be obvious that some affixes have to be added to the end of a word (e.g. -ish), these are called suffixes. Hornby (1985; 865) suffix is letter (s), sound (s), or syllable (s) added at the end of the word to make another word, e.g. $-y$ added to rust to make rusty.

In this research, the researcher would like to describe the affixes that form verbs into nouns, although there are various kinds of forms in affixes. As the researcher had explained in the scope and limitation, in this research the affixes that will be presented below.

\section{(1) Suffixes -ment}

Examples:

Verb + -ment

$\begin{array}{ll}\text { Agree } & \text { agreement } \\ \text { establish } & \text { establishment } \\ \text { govern } & \text { government } \\ \text { manage } & \text { management } \\ \text { improve } & \text { improvement } \\ \text { Etc } & \end{array}$

(2) Suffixes -ance or -ence

Examples:

Verb+ -ance or -ence Noun

assist

assistance

confer

conference

emerge

acquaint

inherit

resemble

emergence

acquaintance

inheritance

resemblance

(3) Suffixes -tion

Examples:

Verb + -tion Noun

celebrate celebration

contribute contribution

cooperate cooperation

amplify amplification

clarify

identify

clarification

Etc

identification

(4) Suffixes -ity

Examples:

Verb + -ity Noun

acid acidity

odd oddity

captive captivity

sensitive sensitivity

extreme extremity

grave gravity

hostile hostility

etc

(5) Suffixes -ary

Examples:

Verb + -ary Noun

discipline disciplinary

planet planetary

fragment fragmentary

vision visionary

legend legendary

prime primary

etc

(6) Suffixes -ness

Examples:

Verb + -ness Noun

aware

heavy

sharp

steady heaviness

sharpness

steadiness 


$\begin{array}{ll}\text { short } & \text { shortness } \\ \text { loud } & \text { loudness } \\ \text { Etc } & \end{array}$

(7) Suffixes -ission

Examples:

$\begin{array}{ll}\text { Verb + -ission } & \text { Noun } \\ \text { admit } & \text { admission } \\ \text { submit } & \text { submission } \\ \text { recede } & \text { recession } \\ \text { commit } & \text { commission } \\ \text { permit } & \text { permission } \\ \text { proceed } & \text { procession }\end{array}$

Etc

\subsection{Prefixes}

According to Yule (2001: 69) in the preceding group of words, it should be obvious that some affixes have to be added to the beginning of a word (e.g. un-), these are called prefixes. In this research, the researcher only takes 4 (four) prefixes that form from verb into noun as well for students' ability, they are:

\section{(1). Prefixes dis-}

Examples:

Verb+ dis-

agree

like

connect

New Meaning
disagree
dislike
disconnect

(2) Prefix mis-

Examples:

Verb+ mis -

behave

calculate

carry

New Meaning
misbehave
miscalculate
miscarry

(3). Prefixes un-

Examples:

Verb+ un-

do

break

New Meaning

undo

Etc

unbreak

\section{Derivational Affixes}

Nida (1974: 255) stated that derivational is studies the principal governing the construction of new words without reference the specific grammar role a word might plan in sentences. Affixes process can change class of word and the meaning. Wordformation process to be found in the production on new English words, this process is called derivation, and it is accomplished by means of a large number of small "bits" of the English language which are not usually given separate listings in dictionaries.

There are some other derivational affixes occur in English words, they are suffixes -al, - $t$, ance or -ence, -(t)ure, -sion, -ssion, - $y$ or -ery, -tion, ation, -ition, -ification, -age, -ant/-ent, -ize, -ate, - ify, -ish, -ary, -ful, -ous, -ic, -ness, -ity, -able or -ible etc. Meanwhile the prefixes could be in the form of un-, dis-, mis-, il-, ir-, in-, im- etc.

In this research the researcher would like to describe and find out the students' ability in constructing the new words of the derivational affixes of -ment, -ance/-ence, -ion, -sion, -tion that form from verbs in to nouns as the limitation of this research.

\section{Inflectional Morphemes}

The word of Inflectional is derived from the verb to inflect. In A.S. Hornby's dictionary stated that inflect means " to change the ending or form of a word to show its relationship to other words in a sentence ". According to Yule (2001:77), Inflectional Morphemes are: Affixes that attached to Verbs, nouns, and adjectives, which are not used to produce new words in English language.

$\mathrm{He}$ also explained that Inflectional morphemes are used to indicate aspects of the grammatical function of a word. Inflectional morphemes are used to show if a word is plural or singular, if it is past tense or not, if it is a comparative or possessive form. English has only eight inflectional morphemes, illustrated in the following sentences:

Let me tell you about Jim's two sisters

One likes to have fun and is always

laughing

The other liked to study and has always

taken things seriously

One is the loudest person in the house and

the other is quieter than a mouse

From these examples we can see that two of the inflections - ' $s$ (possessive) and $-\mathrm{s}$ (plural) are attached to nouns. There are four attached to verbs, $-s$ $\left(3^{\text {rd }}\right.$ persons present singular), -ing (present participle),-ed (past tense), and -en (past participle). There are two inflections, -est (superlative) and -er (comparative) attached to add Adjective. Note that, in English, all inflectional morphemes are suffixes. the inflectional affixes are as follows:

\section{(1). Noun + -'s}

This Inflectional morpheme is to make the genitive (possessive) case of nouns, we normally add -'s to a singular, and an apostrophe 'to' a plural; irregular plurals have $s$. For examples:

$$
\begin{aligned}
& \text { My father's car } \\
& \text { my parents' car } \\
& \text { the children's future }
\end{aligned}
$$

Singular names ending in $-s$ usually have possessive form in - $s$ especially in British English, such as:

$$
\begin{aligned}
& \text { Denis's new job } \\
& \text { Charles'wife }
\end{aligned}
$$

The genitive can be used in several different ways; for examples: Possession, relationship, 
physical features, characteristics, non-physical Qualities, and measurement as in:

$$
\begin{aligned}
& \text { My father's house } \\
& \text { John's mother } \\
& \text { the cat's tail }
\end{aligned}
$$

The - 's genitive can be used as a pronoun, with no following noun (with the same kind of meaning as mine, yours, etc) as in:

Whose is that? - Virginia's

Escalation is neither in Russian's interests nor in the West's

\section{(2). Noun + -s}

This inflectional morpheme is to make the plural form of a singular countable Noun. The ways of making the plural nouns are:

a. By adding -es to nouns ending in these letters: $-s$, ss, - sh, - ch, and $-x$.

$\begin{array}{lc}\text { SINGULAR } & \text { PLURAL } \\ \text { Bus } & \text { Buses } \\ \text { Brush } & \text { Brushes } \\ \text { Branch } & \text { Branches }\end{array}$

b. Nouns ending in -ywith a consonant before it make the plural by changing $-y$ to ies. But if the $-y$ has a vowel letter before it, the plural is made in the regular way by adding $s$. Compare the two lists:

$\begin{array}{lc}\text { SINGULAR } & \text { PLURAL } \\ \text { Baby } & \text { Babies } \\ \text { City } & \text { Cities } \\ \text { Country } & \text { Countries } \\ \text { Boy } & \text { Boys } \\ \text { Day } & \text { Days } \\ \text { Tray } & \text { Trays }\end{array}$

c. Some, but not all nouns ending in $f$ or $f e$ make the plural with the ending ves. For examples:

$\begin{array}{ll}\text { SINGULAR } & \text { PLURAL } \\ \text { Wife } & \text { Wives } \\ \text { Knife } & \text { Knives } \\ \text { Life } & \text { Lives }\end{array}$

\section{(3). Verb + -s}

This inflectional morpheme is to make the present tense. Inflectional morpheme Verb $+-\mathrm{s}$ is added to the stem after the pronouns he, she, and it, or after nouns for which these pronouns are used. For examples:

He drinks a cup of coffee

the man sleeps at eleven

\section{(4). Verb + -ing}

Progressive tenses (also called continuous tenses) are the ones made with form Verb + -ing. They include the present and past progressive (e.g. I am waiting, I was waiting), the future and conditional progressive (e.g. I will be waiting, I would be waiting), the present and past progressive tense (I have been waiting, I had been waiting), and the future and conditional perfect progressive (I will have been waiting, I would have been waiting).

The term of verb + -ing is sometimes called (a). The present participle and sometimes (b) the gerund, depending on whether it is used (a) more like a verb or adjective or (b) more like a noun.

\section{(5). Verb + -ed}

This inflectional morpheme is used for regular verbs of the past participle, which ended in ed just like past tense. For examples:

$$
\begin{array}{lll}
\text { Walk } & \multicolumn{2}{c}{\text { Walked }} \\
& \text { Call } & \text { Called } \\
& \text { Study } & \text { Studied }
\end{array}
$$

\section{(6). Verb + -en}

This inflectional morpheme is used for Irregular verbs of the past participle which Ended in -en to form perfect tense and the passive form. For examples:

She has taken a bath

the boys have written

I will have been forgotten

(7). Adjective + -er, -est

Affixes of Adjective $+-e r$ and -est are used to make comparative and superlative adjective. The rules of the writing are as follows:

a. Adjective in ending in $-e$ add $-r$ and $-s t$; adjectives with one vowel followed by one consonant double the final consonant as in:

$$
\begin{array}{lll}
\text { Old } & \text { older } & \text { oldest } \\
\text { Cheap } & \text { cheaper } & \text { cheapest }
\end{array}
$$

In this research, the researcher would like to describe and find out the students' ability in constructing the new words using the derivational and inflectional affixes. The inflectional affixes that the researcher would like to analyze are the verb forms, they are new words verb $+-s$, -ing, - ed, and en.

\section{Conceptual Framework}

A morpheme is divided into two kinds (free morpheme and bound morpheme). Bound morpheme can be divided into two affixes (derivational and inflectional affix). An affix is a morpheme that only occurs when attached to some other morpheme or morphemes such as a root, stem or new words. There are two types of affixes (prefixes and suffixes).

In this research the researcher would like to find out the students' ability in constructing the new words using derivational that the new words are verbs and adjectives formed into nouns, they are suffixes -ment, -ancel-ence, -ion, -sion, -ission, -tion, -ity, -ary, -ness.

\section{METHODELOGY}

In this research, the researcher used descriptive quantitative method. This study applied on 
quantitative method. The quantitative method is a research, which is used to analyze the students' ability in constructing the new words using derivational affixes. As Cauvery (2003:30) explains that this method describes the students' ability in constructing the new words using derivational affixes and identified the students' problems. To obtain the students' ability, the researcher used what Sudijono (1999:76) suggested by using the following formula:

$Q=\frac{x}{y} x 100 \%$ or $\mathrm{M}_{\mathrm{x}}=\frac{\sum x}{N}$

\section{FINDINGS AND DISCUSSION}

The test was regarded as reliabilty (0.93) the of course the tset was good enough to measure the students' ability in constructing the new words using derivational affixxes -ment, -ance/-ence, -ion, -sion, -ission, -tion, -ity, -ary, -ness. It showed that 18 studens or $75 \%$ from the whole sample where able to answer the test correctly and only 12 students or 25 $\%$ from the sample were unable to answer the tset, so the 2005/2006 first year (X Class) of SMK ALFATTAH Jl Cemara No. 172, Medan in academic year of 2005/2006 were able to construc the new words using derivational affixes -ment, -ancel-ence, -ion, -sion, -ission, -tion, -ity, -ary, -ness.

The difficulty that the students had is in suffix -ance/-ence from as shown in the test item number 10 in which only 5 students could answer correctly.

\section{CONCLUSIONS AND SUGGESTIONS \\ A. Conclusion}

After analyzing the data, some conclusions of the present research are stated as follows:

1. From 24 dtudents there were 18 students or 75 $\%$ were categorized as able. Meanwhile there were 6 students or $25 \%$ were categorized as unable. So, from the data obtained, it may conclude that students of SMK

AL-

FATTAH Jl Cemara No. 172 Medan at the first year or X Class during the academic year of 2005 / 2006 were able in constructing the new words using derivational affixes -ment, -ance/ence, -ion, -sion, -ission, -tion, -ity, -ary, -ness.

2. The test item number 10 was the most difficult one in which only 5 students who could answer the test correctly among the 20 test items. The test item was related to suffix -ence. From the data obtained, it may conclude that the students of SMK ALFATTAH Jln Cemara No.172 Medan at the first year during the academic year of 2005 / 2006 had difficulty in constructing the new words using derivational affixes -ment, ancel-ence, -ion, -sion, -ission, -tion, -ity, -ary, ness. Was at the affix-ence,

\section{B. Suggestions}

In relation to conclusions previously stated, the suggestions are as follows:

1. The students must able to motivate themselves to like English subjects espicially in English vocabulary in order to ease them receiveEnglish lessons,

2. There were $75 \%$ of the stuents who were categorized as able, so it is suggested the students should improve their knowledge in derivational affixes,

3. The students who were still in the status of poor and very poor should learn more diligently especially in mastring the English suffixes by having practis, reading grammar and asking to their teachers and attend the out of school hour activities,

4. The students were suggested to learn more bout English suffixes, especially in constructing the new words using derivational affixex -ment, ance/-ence, -ion, -sion, -ission, -tion, -ity, -ary, ness.

5. In teaching English as forign language, it is expected that the teacher give some motivations, explanation, examples that can be understood by the students so that they can receive the lessons easily,

6. In teaching English, it is expected that the teacher can use as an intersting method, creating some games related to the lessons so that the students may interest in learning English and they may think that English is easy to learn and practice in vacabulary.

\section{REFERENCES}

Arikunto. S, 2002, Prosedur Penelitian,Jakarta:Rineka Cipta Press.

Cauvery, $\mathrm{R}$ and friends, 2003, Research Methodology, New Delhi: S. Chand\& Co.

Coates, Richard, 1999, Word Structure, London:Routledge London \& New York.

Dickey, James. 1986. Mac Millan English. New York: Scribner Educational Publisher.

Hornby, A.S, 1995, Oxford Advanced Learners Dictionary of Current English, Britain:Oxford University Press.

Kumar, E.R Ram, 2004, Handbook of English Usage for Editors, Writers and Executives, Mumbai: Jaico Publishing House.

Lambert, J.J. 1972. A Short Introduction To English Usage.New York: Mc Grawhill.

Nida, Eugene. 1974. Morphology:TheDescriptive Analysis Of Words. Ann Arbor: University Of 
Michigas Press

Pickthall, Marmadake (Unidentified Year). The Meaning Of the Glorious Qur'an Karachi; Raj, Company Ltd.

Perrin, G. Peter, 1979, Writer's Guide and Index to English, London : Scott \& Co

Quirk, Randolph, 1988, Longman Dictionary of Contemporary English, England: Longman.

Rachmadie, Sabrony, $1985 . \quad$ Vocabulary, Jakarta:DepdikbudUniversitas Terbuka.

Sudijono, Anas. 1999. Pengantar Evaluasi Pendidikan. Jakarta: Raja Grafindo Persada.

Wardhaugh, Ronald, and Brown, Douglas. 1996. A Survey Of Applied Linguistics. The University Of Michigan Press.

Webster's, Merriam, 1995, Pocket Guide to Punctuation, Massachusettes, MerriamWebster Incorporation.

Yule, George, 2001, The Study Of Language, Cambridge University Press. 